\title{
Hematological parameters of three species of the peacock bass (Cichla spp.) from Balbina lake, Presidente Figueiredo, Amazonas, Brazil
}

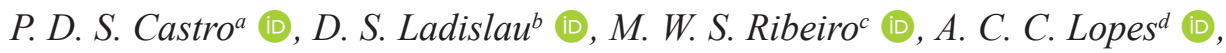 \\ H. D. Lavandere (D, L. A. Bassule (D), D. C. Mattos f (D), A. R. S. Liebl I (D, P. H. R. Aride \\ and A. T. Oliveira ${ }^{h}$ * \\ ${ }^{a}$ Laboratório de Fisiologia Animal, Universidade Federal do Amazonas - UFAM, Av. General Rodrigo Octávio Jordão \\ Ramos, 3000, CEP 69077-000, Manaus, AM, Brasil
}

bPrograma de Pós-graduação em Recursos Pesqueiros e Engenharia de Pesca - PREP, Universidade Estadual do Oeste do Paraná - UNIOESTE, Rua da Faculdade, 645, Jardim La Salle, CEP 85903-000, Toledo, PR, Brasil

'Programa de Pós-graduação em Aquicultura, Instituto Nacional de Pesquisas da Amazônia - INPA, Universidade Nilton Lins, Av. Professor Nilton Lins, 3260, Parque das Laranjeiras, CEP 69058-040, Manaus, AM, Brasil

dPrograma de Pós-graduação em Zoologia, Laboratório de Fisiologia Animal, Universidade Federal do Amazonas UFAM, Av. General Rodrigo Octávio Jordão Ramos, 3000, CEP 69077-000, Manaus, AM, Brasil

eInstituto Federal de Educação, Ciência e Tecnologia do Espírito Santo - IFES, Campus Piúma, Rua Augusto Costa de Oliveira, 660, CEP 29285-000, Piúma, ES, Brasil

fUniversidade de Vila Vilha - UVV, Av. Comissário José Dantas de Melo, 21, Boa Vista II, CEP 29102-920, Vila Velha, ES, Brasil

gPrograma de Pós-graduação em Ciências Pesqueiras nos Trópicos - CIPET, Universidade Federal do Amazonas - UFAM, Av. General Rodrigo Octávio Jordão Ramos, 3000, CEP 69077-000, Manaus, AM, Brasil

h'Instituto Federal de Educação, Ciência e Tecnologia do Amazonas - IFAM, Campus Manaus Centro - CMC, Av. Sete de Setembro, 1975, CEP 69020-120, Manaus, AM, Brasil

*e-mail: adriano.oliveira@ifam.edu.br

Received: February 14, 2019 - Accepted: October 8, 2019 - Distributed: February 28, 2021

\begin{abstract}
The objective of this study was to characterize and compare the hematological variables (erythrogram, thrombogram, leukogram and plasma metabolites) of three cichlid species: Cichla monoculus, Cichla temensis and Cichla vazzoleri. A total of 45 specimens were captured in Balbina lake, Presidente Figueiredo, Amazonas, Brazil, with the aid of a rod and reel or hand line, with natural or artificial bait: 15 C. monoculus, 15 C. temensis and 15 C. vazzoleri. Their blood was removed by means of caudal puncture of the dorsal aorta, and hematological data were determined in accordance with methodology previously described in the literature. The erythrogram showed similarities between the species, while the thrombogram showed differences between $C$. vazzoleri and the other species studied (C. monoculus and C. temensis). The total leukocyte counts for C. temensis and C. vazzoleri were higher than those of C. monoculus. The predominant leukocyte in C. temensis and C. vazzoleri was lymphocytes, whereas it was monocytes in C. monoculus. The plasma metabolites showed differences between the three cichlid species, regarding their glucose, cholesterol, urea and potassium levels. It is concluded that these three species present hematological differentiation, thus indicating that they have differentiated blood-cell immune responses and plasma metabolite physiology.
\end{abstract}

Keywords: Amazon region, cichlid fish, blood, welfare, comparison.

\section{Parâmetros hematológicos de três espécies de tucunarés (Cichla spp.) do lago de Balbina, Presidente Figueiredo, Amazonas, Brasil}

\section{Resumo}

O presente trabalho teve por objetivo caracterizar e comparar as variáveis hematológicas (eritrograma, trombograma, leucograma e metabólitos plasmáticos) de três espécies de tucunarés Cichla monoculus, Cichla temensis e Cichla vazzoleri. Um total de 45 animais foi capturado no lago de Balbina, Presidente Figueiredo, Amazonas, com auxílio de vara e carretilha, linha de mão com isca natural e artificial, sendo 15 C. monoculos, 15 C. temensis e 15 C. vazzoleri. O sangue foi retirado por punção caudal da aorta dorsal e os dados hematológicos foram determinados de acordo com metodologia previamente descrita na literatura. No eritrograma foram observadas similaridades entre as espécies, o 
trombograma demonstrou diferenças entre o $C$. vazzoleri e as demais espécies estudadas (C. monoculus e C. temensis), a contagem total de leucócitos demonstrou que em $C$. temensis e $C$. vazzoleri os valores são superiores ao $C$. monoculus. Foi demonstrado que os linfócitos foram às células predominantes em C. temensis e C. vazzoleri, diferentemente do C. monoculos que apresentou como leucócito predominante os monócitos. Nos metabólitos plasmáticos, foi possível observar diferenças entre as três espécies de tucunarés nos níveis de glicose, colesterol, uréia e potássio. Conclui-se que as três espécies de tucunarés apresentam diferenciação hematológica, indicando que as mesmas possuem respostas diferenciadas, na resposta imunológica de suas células do sangue e na fisiologia dos metabólitos plasmáticos.

Palavras-chave: Amazônia, peixe ciclídeo, sangue, bem estar, comparação.

\section{Introduction}

Peacock bass are species in the order Perciformes and family Cichlidae. This family stands out among bony fish, not only because of its large number of species (nearly 1300), but also because of its wide geographical distribution (Kullander, 1998). These species encompass individuals that present size variations from small to large, as well as wide differences in coloration patterns (Kullander, 1998).

Among the cichlids, species of the genus Cichla are prominent. These have great ecological importance: they are considered to be predators at the top of the food chain, with piscivorous habits (Kullander and Ferreira, 2006; Santos et al., 2006). They are edible fish, and form the main white group for sport fishing in the Amazon region.

Blood parameters have been used to monitor fish health, determine occurrences of stress and aid in analyses on the general state of fish population health (Tavares-Dias and Moraes, 2004, 2007; Pavlidis et al., 2007; Aride et al., 2007, 2010, 2018; Ferreira et al., 2013; Oliveira et al., 2017a, b).

Erythrograms can be used to diagnose anemia and to characterize different fish population strategies regarding their metabolic demand for oxygen (Wilhelm Filho et al., 1992). They are also the main indicator for different physiological strategies relating to environmental variations (Val et al., 1992; Almeida-Val et al., 1999).

Quantification of leukocytes (white series) in blood provides an indication of the state of immunological defense (Tavares-Dias and Moraes, 2007; Pavlidis et al., 2007). Analysis on plasma metabolites enables correlations with feeding, body ion regulation and the integration between the organism and the atmosphere.

One characteristic of fish is their wide interspecific hematological variation (Parma-Croux, 1994; Tavares-Dias et al., 2004; Kori-Siakpere et al., 2005; Tavares-Dias and Moraes, 2007). In general, these variations are attributed to genetic variations such as nutritional state, sex, age, capture stress, manipulation procedures and blood sampling (Tavares-Dias and Moraes, 2004; Kori-Siakpere et al., 2005).

Although hematological evaluation of fish is a valuable tool, progress in establishing hematological parameters is slow and the literature is fragmented and frequently incomplete (Kori-Siakpere et al., 2005). Among the gaps in the literature are data relating to peacock bass species.

The aim of the present study was to characterize and compare the hematology of three species of peacock bass from Balbina lake, Presidente Figueiredo, Amazonas, Brazil.

\section{Material and Methods}

The Balbina hydroelectric power station is located on the Uatumã river, $155 \mathrm{~km}$ to the north of the capital of the state of Amazonas (Manaus). Fish were caught with the aid of professional fishermen. Natural and artificial baits and boats and nets were used. Four field collections were accomplished and 67 specimens of peacock bass were caught. These comprised 30 specimens of Cichla monoculus, 22 of Cichla temensis and 15 of Cichla vazzoleri. Blood samples were collected by means of puncturing the dorsal aorta using disposable syringes containing the anticoagulant heparin (5000 IU).

Immediately after the blood samples had been collected, biometry was done, consisting of measurement of total length $(\mathrm{cm})$ using a measuring tape and body weight $(\mathrm{g})$ using portable scales. After these handling procedures, the fish were returned to the natural environment.

Hematocrit (Ht, \%) was determined using the microhematocrit technique. Hemoglobin concentration ([Hb], g/dL) was determined in accordance with the cyanmethemoglobin method. Red blood cell counts (RBC, millions $/ \mathrm{mm}^{3}$ ) were done in a Neubauer chamber using an optical microscope. After obtaining these parameters, the following blood indices were determined: mean corpuscular volume (MCV, fL), mean corpuscular hemoglobin $(\mathrm{MCH}, \mathrm{pg})$ and mean corpuscular hemoglobin concentration (MCHC, g/dL), in accordance with the methodology described by Wintrobe (1934).

Characterization and morphological identification of the blood cells followed the methodology of Tavares-Dias and Moraes (2004), after making extensions and doing staining with May-Grünwald-Giemsa-Wright (MGGW) (Tavares-Dias and Moraes, 2003; Oliveira et al., 2011, 2016, 2017c). Differential leukocyte counts were done on blood extensions and the percentage of each cell component was determined. These blood extensions were also used to estimate leukocyte counts and total thrombocyte counts (Tavares-Dias et al., 2004).

After blood separation by means of centrifugation, plasma samples were immediately frozen in liquid nitrogen. The levels of glucose $(\mathrm{g} / \mathrm{dL})$, total proteins $(\mathrm{g} / \mathrm{dL})$, triglycerides $(\mathrm{mM} / \mathrm{L})$, cholesterol $(\mathrm{mM} / \mathrm{L})$ and urea $(\mathrm{mM} / \mathrm{L})$ were ascertained using specific enzyme kits $\left(\right.$ Labtest $\left.{ }^{\circledR}\right)$ and were read by means of spectrophotometry. The sodium $(\mathrm{mEq} / \mathrm{L})$, potassium $(\mathrm{mEq} / \mathrm{L})$ and chloride $(\mathrm{mM} / \mathrm{L})$ plasma ion levels were also ascertained, using enzyme kits (Labtest ${ }^{\circledR}$ ) that were specific for each constituent. These levels were also read by means of spectrophotometry. 
Water samples were collected to determine the temperature $\left({ }^{\circ} \mathrm{C}\right), \mathrm{pH}$ and dissolved oxygen levels $(\mathrm{mg} / \mathrm{L})$ (Digital WTW-310i; WTW, Germany). The Shapiro-Wilk normal distribution test was performed on the data. The blood parameters and water quality were compared among the experimental treatments by means of the Kruskal-Wallis test. The LSD test was used for multiple comparisons and $\mathrm{p}<0.05$ was taken to be the statistical significance level. All of the analyses mentioned above were based on Zar (1999) and Siegel and Castellan (2006).

\section{Results}

The mean values and standard deviations of the biometric measurements and the red series of Cichla monoculus, Cichla temensis and Cichla vazzoleri are reported in Table 1 . There was a statistically significant difference in total length between $C$. temensis and C. vazzoleri, while the lengths of $C$. temensis and $C$. monoculus were similar. However, regarding weight, no statistical differences were observed between the species.

The presence of red blood cells, thrombocytes, lymphocytes, heterophils and basophils was observed in the blood samples of the three species of peacock bass. The thrombogram showed similarity among the three species investigated (Table 2). The total leukocyte counts in $C$. temensis were higher than those of the other species. It was demonstrated that lymphocytes were predominant in C. temensis and C. vazzoleri, but this was not repeated in C. monoculus, in which monocytes predominated (Table 2).

Table 3 shows the plasma metabolite results. There were significant differences among the three species of peacock bass in relation to almost all the parameters analyzed, except for cholesterol and sodium levels. Table 4 shows the physical parameters of water at the location where

Table 1. Biometrics and erythrogram (mean \pm standard deviation; minimum-maximum) of three species of peacock bass (Cichla spp.) from Balbina Lake, Presidente Figueiredo, Amazonas, Brazil.

\begin{tabular}{lccc}
\hline \multicolumn{1}{c}{ Variables } & C. monoculus & C. temensis & C. vazzoleri \\
\hline Total length $(\mathrm{cm})$ & $26.44 \pm 2.68^{\mathrm{ab}}$ & $29.16 \pm 6.63^{\mathrm{a}}$ & $25.16 \pm 3.01^{\mathrm{b}}$ \\
& $(21.00-30.00)$ & $(18.00-48.00)$ & $(21.00-29.00)$ \\
Weight $(\mathrm{g})$ & $425.72 \pm 93.03^{\mathrm{a}}$ & $457.95 \pm 273.26^{\mathrm{a}}$ & $313.50 \pm 75.75^{\mathrm{a}}$ \\
& $(260.00-620.00)$ & $(148.00-1054.00)$ & $(220.00-430.00)$ \\
Hematocrit (\%) & $40.37 \pm 1.17^{\mathrm{a}}$ & $40.48 \pm 1.59^{\mathrm{a}}$ & $40.40 \pm 1.06^{\mathrm{a}}$ \\
& $(38.61-42.13)$ & $(38.10-42.86)$ & $(38.82-41.98)$ \\
Hemoglobin $\left(\mathrm{g} . \mathrm{dL}^{-1}\right)$ & $5.69 \pm 0.46^{\mathrm{a}}$ & $5.55 \pm 0.36^{\mathrm{a}}$ & $5.66 \pm 0.34^{\mathrm{a}}$ \\
& $(5.00-6.38)$ & $(5.01-6.09)$ & $(5.16-6.17)$ \\
RBC (million/ $\mu \mathrm{L})$ & $1.84 \pm 0.20^{\mathrm{a}}$ & $1.79 \pm 0.28^{\mathrm{a}}$ & $1.70 \pm 0.19^{\mathrm{a}}$ \\
& $(1.54-2.14)$ & $(1.38-2.21)$ & $(1.41-1.99)$ \\
MCV (fL) & $222.94 \pm 25.94^{\mathrm{a}}$ & $234.82 \pm 31.70^{\mathrm{a}}$ & $246.11 \pm 20.46^{\mathrm{a}}$ \\
& $(184.03-261.85)$ & $(187.27-282.37)$ & $(215.43-276.80)$ \\
MHC (pg) & $31.63 \pm 4.14^{\mathrm{a}}$ & $32.98 \pm 3.71^{\mathrm{a}}$ & $34.39 \pm 2.86^{\mathrm{a}}$ \\
MCHC (g.dL & $(27.41-38.54)$ & $(30.11-38.68)$ \\
& $(25.42-37.83)$ & $13.86 \pm 0.90^{\mathrm{a}}$ & $14.19 \pm 1.12^{\mathrm{a}}$ \\
\hline
\end{tabular}

Different letters represent statistically significant differences $(\mathrm{p}<0.05)$.

Table 2. Thrombogram and leukogram (mean \pm standard deviation; minimum-maximum) of three species of peacock bass (Cichla spp.) from Balbina Lake, Presidente Figueiredo, Amazonas, Brazil.

\begin{tabular}{lccc}
\hline \multicolumn{1}{c}{ Variables } & C. monoculus & C. temensis & C. vazzoleri \\
\hline Thrombocytes $(\mu \mathrm{L})$ & $1,394.23 \pm 78.42^{\mathrm{a}}$ & $1,529.93 \pm 84.78^{\mathrm{a}}$ & $1,145.1 \pm 582.37^{\mathrm{b}}$ \\
& $(1,276.59-1,511.87)$ & $(1,402.75-1,657.10)$ & $(272.15-2,019.26)$ \\
Leukocytes $(\mu \mathrm{L})$ & $4,228.46 \pm 1,518.83^{\mathrm{a}}$ & $5,279.90 \pm 1,361.12^{\mathrm{b}}$ & $4,794.20 \pm 918.40^{\mathrm{ab}}$ \\
& $(1,950.22-6,506.70)$ & $(3,238.22-7,321.58)$ & $(3,416.60-6,171.80)$ \\
Lymphocytes $(\mu \mathrm{L})$ & $1,565.37 \pm 779.18^{\mathrm{a}}$ & $1,868.31 \pm 599.64^{\mathrm{a}}$ & $1,846.24 \pm 910.53^{\mathrm{a}}$ \\
& $(396.60-2,734.14)$ & $(968.86-2,767.77)$ & $(480.45-3,212.03)$ \\
Monocytes $(\mu \mathrm{L})$ & $1,638.81 \pm 1,123.52^{\mathrm{a}}$ & $1,324.00 \pm 615.39^{\mathrm{a}}$ & $1,665.82 \pm 508.00^{\mathrm{a}}$ \\
& $(46.47-3,324.09)$ & $(400.91-2,247.09)$ & $(903.82-2,427.82)$ \\
Heterophils $(\mu \mathrm{L})$ & $754.86 \pm 265.71^{\mathrm{a}}$ & $1,010.08 \pm 363.94^{\mathrm{a}}$ & $950.38 \pm 269.65^{\mathrm{a}}$ \\
& $(356.30-1,153.43)$ & $(464.17-1,555.99)$ & $(545.90-1,354.86)$ \\
Basophils $(\mu \mathrm{L})$ & $109.68 \pm 49.90^{\mathrm{a}}$ & $108.90 \pm 62.83^{\mathrm{a}}$ & $140.26 \pm 67.79^{\mathrm{a}}$ \\
& $(34.83-184.53)$ & $(14.65-203.15)$ & $(38.57-241.94)$
\end{tabular}

Different letters represent statistically significant differences $(\mathrm{p}<0.05)$. 
Table 3. Plasma metabolites (mean \pm standard deviation; minimum-maximum) of three species of peacock bass (Cichla spp.) from Balbina lake, Presidente Figueiredo, Amazonas, Brazil.

\begin{tabular}{|c|c|c|c|}
\hline Variables & C. monoculus & C. temensis & C. vazzoleri \\
\hline Total protein $\left(\mathrm{g} \cdot \mathrm{dL}^{-1}\right)$ & $\begin{array}{l}1.01 \pm 0.24^{\mathrm{a}} \\
(0.65-1.37)\end{array}$ & $\begin{array}{l}0.84 \pm 0.26^{\mathrm{a}} \\
(0.44-1.24)\end{array}$ & $\begin{array}{l}0.72 \pm 0.21^{\mathrm{a}} \\
(0.40-1.03)\end{array}$ \\
\hline Glucose (mg.dL $\left.{ }^{-1}\right)$ & $\begin{array}{l}25.92 \pm 5.70^{\mathrm{a}} \\
(17.38-34.47)\end{array}$ & $\begin{array}{l}34.00 \pm 3.66^{b} \\
(28.51-39.50)\end{array}$ & $\begin{array}{l}27.70 \pm 4.93^{\mathrm{a}} \\
(20.31-35.09)\end{array}$ \\
\hline Triglycerides $\left(\mathrm{mM} \cdot \mathrm{L}^{-1}\right)$ & $\begin{array}{l}0.61 \pm 0.25^{\mathrm{a}} \\
(0.24-0.98)\end{array}$ & $\begin{array}{l}0.61 \pm 0.11^{\mathrm{a}} \\
(0.45-0.78)\end{array}$ & $\begin{array}{c}0.55 \pm 0.10^{\mathrm{a}} \\
(0.40-0.71)\end{array}$ \\
\hline Total cholesterol $\left(\mathrm{mM} \cdot \mathrm{L}^{-1}\right)$ & $\begin{array}{l}1.36 \pm 0.44^{\mathrm{a}} \\
(0.70-2.03)\end{array}$ & $\begin{array}{c}0.89 \pm 0.19^{b} \\
(0.61-1.18)\end{array}$ & $\begin{array}{l}0.94 \pm 0.22^{b} \\
(0.61-1.28)\end{array}$ \\
\hline Urea $\left(\mathrm{g} \cdot \mathrm{dL}^{-1}\right)$ & $\begin{array}{c}0.65 \pm 0.14^{\mathrm{a}} \\
(0.45-0.85)\end{array}$ & $\begin{array}{c}0.54 \pm 0.12^{b} \\
(0.36-0.73)\end{array}$ & $\begin{array}{c}0.52 \pm 0.08^{b} \\
(0.40-0.63)\end{array}$ \\
\hline Chloride (mM.L-1) & $\begin{array}{c}128.07 \pm 9.30^{\mathrm{a}} \\
(114.12-142.02)\end{array}$ & $\begin{array}{c}120.56 \pm 7.79^{a} \\
(108.88-132.24)\end{array}$ & $\begin{array}{c}128.73 \pm 9.25^{\mathrm{a}} \\
(114.85-142.61)\end{array}$ \\
\hline Sodium (mM.L-1) & $\begin{array}{c}121.65 \pm 7.79^{a} \\
(109.97-133.33)\end{array}$ & $\begin{array}{c}121.67 \pm 4.62^{\mathrm{a}} \\
(114.74-128.60)\end{array}$ & $\begin{array}{c}118.20 \pm 5.06^{\mathrm{a}} \\
(110.61-125.79)\end{array}$ \\
\hline Potassium (mM.L-1) & $\begin{array}{l}8.26 \pm 0.61^{\mathrm{a}} \\
(7.34-9.17)\end{array}$ & $\begin{array}{l}10.28 \pm 142^{b} \\
(8.15-12.41)\end{array}$ & $\begin{array}{l}9.39 \pm 1.46^{b} \\
(7.20-11.59)\end{array}$ \\
\hline
\end{tabular}

Different letters represent statistically significant differences $(\mathrm{p}<0.05)$.

Table 4. Physical parameters (mean \pm standard deviation; minimum-maximum) of water from Balbina Lake at the location where three species of peacock bass (Cichla spp.) were caught.

\begin{tabular}{lccc}
\hline \multicolumn{1}{c}{ Variables } & C. monoculus & C. temensis & C. vazzoleri \\
\hline $\mathrm{pH}$ & $5.23 \pm 0.64^{\mathrm{a}}$ & $4.92 \pm 0.12^{\mathrm{a}}$ & $5.21 \pm 0.36^{\mathrm{a}}$ \\
& $(4.27-6.19)$ & $(4.75-5.10)$ & $(4.67-5.76)$ \\
Temperature $\left({ }^{\circ} \mathrm{C}\right)$ & $29.73 \pm 1.44^{\mathrm{a}}$ & $29.84 \pm 0.44^{\mathrm{a}}$ & $30.07 \pm 1.39^{\mathrm{a}}$ \\
& $(27.58-31.89)$ & $(29.18-30.50)$ & $(27.99-32.15)$ \\
Dissolved oxygen $\left(\mathrm{mg} . \mathrm{L}^{-1}\right)$ & $5.21 \pm 0.20^{\mathrm{a}}$ & $5.02 \pm 0.17^{\mathrm{a}}$ & $5.15 \pm 0.20^{\mathrm{a}}$ \\
& $(4.85-5.45)$ & $(4.77-5.27)$ & $(4.84-5.45)$ \\
\hline
\end{tabular}

Different letters represent statistically significant differences $(\mathrm{p}<0.05)$.

three species of peacock bass, no statistical differences were found between the three species (C. monoculus, C. temensi and C. vazzoleri).

\section{Discussion}

The Ht values of the erythrogram were similar among the species of peacock bass of Balbina lake. These individuals presented values that were higher than those of $C$. temensis $(23.9 \pm 2.1 \%)$ found by Tavares-Dias et al. (2011) and lower than those of C. monoculus $(58.0 \pm 1.0 \%)$ found by Ranzani-Paiva et al. (2000). The variations among fish of the same genus were related to the methodology used in each of the previous studies. In a study on Cichla temensis by Tavares-Dias et al. (2004), the anticoagulant used was $10 \%$ EDTA, while in a study on Cichla monoculus by Ranzani-Paiva et al. (2000), heparin was used. The hematocrit values and hemoglobin concentrations are greater in samples for which heparin was used than in samples for which EDTA was used, among the same fish (Tavares-Dias and Sadrim, 1988).

The $\mathrm{Hb}$ values were similar $(\mathrm{p}>0.05)$ among the three species: 5.69 g.dL $\mathrm{dL}^{-1}, 5.55$ g.dL $\mathrm{dL}^{-1}$ and 5.66 g.dL $\mathrm{dL}^{-1}$ for C. monoculus, C. temensis and $C$. vazzoleri respectively. However, in a study by Tavares-Dias et al. (2011) on
C. temensis from fish farming, the values were higher $\left(6.3 \pm 0.6\right.$ g. $\left.\mathrm{dL}^{-1}\right)$ than those of the species investigated in the present study. This was also observed in a study by Ranzani-Paiva et al. (2000), in which values of $8.2 \pm 0.5$ g.dL $\mathrm{dL}^{-1}$ were found among specimens of $C$. monoculus originating from the Paraná river.

The RBC values were similar among the three species of peacock bass from Balbina lake, thus indicating that similar red cells were produced among the species investigated. In the study by Tavares-Dias et al. (2011) on C. temensis, the $\mathrm{RBC}$ values were $1.42 \pm 0.12 \mathrm{million} / \mu \mathrm{L}$, i.e. lower than those of the peacock bass from Balbina lake. The MCV values were similar among the species and were higher than those in C. monoculus $(197.5 \pm 1.8 \mathrm{fL})$ found by Ranzani-Paiva et al. (2000) and in C. temensis (168.3 $\pm 4.6 \mathrm{fL}$ ) found by Tavares-Dias et al. (2011).

The MCH was higher than what was reported by Tavares-Dias et al. (2011) for C. monoculus $(27.9 \pm 1.0 \mathrm{pg})$. For the MCHC, there was a difference between the species C. monoculus and C. temensis. The MCHC values of the three peacock bass species were lower $(26.4 \pm 1.2 \mathrm{~g} / \mathrm{dL})$ than those found in C. temensis by Tavares-Dias et al. (2011) and similar to those of $C$. monoculus $(14.1 \pm 0.6 \mathrm{~g} / \mathrm{dL})$ reported by Ranzani-Paiva et al. (2000). 
The erythrogram values among the species C. monoculus, C. temensis and $C$. vazzoleri were similar $(\mathrm{p}>0.05)$. They were higher than those of $C$. temensis from fish farming (Tavares-Dias et al., 2011) and were lower than those of C. monoculus originating from natural areas of the Paraná river (Ranzani-Paiva et al., 2000). These erythrogram values can be directly correlated with the fact that the peacock bass is classified as a carnivorous fish and presents high levels of natatory activity, especially when catching their prey, which requires high levels of oxygen dissolved in the water (Tavares-Dias et al., 2011).

The variables of the thrombogram and leukogram are associated with the process of blood coagulation among defense cells from teleost fish species (Tavares-Dias and Moraes, 2004). In the present study, the thrombocyte counts and total leukocyte counts among the peacock bass species presented significant differences. In C. temensis studied by Tavares-Dias et al. (2011), the thrombocyte count was higher than that of the present study $(28.619 \pm 13.148 \mathrm{uL})$, thus indicating that exists accentuated increase of that cell type that can be associated to the environmental type. In that case it adapts of captivity.

The total leukocyte count relating to C. monoculus was lower than the counts for the other species in the present study. In a study by Ranzani-Paiva et al. (2000) on C. monoculus, this type of analysis was not used. For $C$. temensis, the total leukocyte count was higher $(13.163 \pm 6.857 \mathrm{uL})$, thus demonstrating that there was differentiation among the species.

Differentiation of the blood cell types demonstrated the presence of lymphocytes, monocytes, heterophils and basophils in the three species of peacock bass from Balbina lake. The predominant type in C. temensis and C. vazzoleri was lymphocytes, thus indicating that in those species, leukocytes were the main defense cell in the blood. In the studies developed by Ranzani-Paiva et al. (2000) and Tavares-Dias et al. (2011) on C. monoculus and $C$. temensis respectively, lymphocytes also accounted for the largest percentage of the cell types in the blood $(59.2 \pm 27.5 \% ; 9.308 \pm 5.864 \mathrm{uL})$. Lymphocytes act basically in inflammatory processes. They are cells that deal with a variety of situations (Iwama and Nakanishi, 1996).

There were no significant differences in monocyte levels in the three species investigated. However, for C. monoculus the main leukocyte was monocytes. This demonstrated that this species presents a differentiated immune defense profile in its blood cells. Although alterations due to the sexual profile or ontogeny may occur, this was not proven in the present study. Monocytes are precursor cells for macrophages that have the main function of phagocytic activity and elimination of bacteria (Tavares-Dias and Moraes, 2004).

In $C$. monoculus, it was previously observed that monocytes were the third commonest type $(5.9 \pm 1.1 \%)$ of leukocyte in the blood (Ranzani-Paiva et al., 2000), while in $C$. temensis monocytes were the second commonest type of leukocyte $(9.308 \pm 5.864 \mathrm{uL})$ (Tavares-Dias et al., 2011). Those values were higher than the values in the peacock bass in present study.
Regarding thrombocytes, similarity between species was also observed in peacock bass. This type was not present in the blood of C. monoculus (Ranzani-Paiva et al., 2000) or C. temensis (Tavares-Dias et al., 2011). Regarding basophils, $C$. temensis was found to present lower values in relation to other species. Basophils were not also observed in the blood of C. temensis (Tavares-Dias et al., 2011) or C. monoculus (Ranzani-Paiva et al., 2000). Hematological studies on fish have shown that this is the type of leukocyte that is most difficult to find in blood extensions (Tavares-Dias and Moraes, 2004). Basophils were only found to occur during gonadal maturation in Prochilodus scrofa (Ranzani-Paiva and Godinho, 1983), which may be indicative of an active reproduction process.

Regarding total protein levels, lower values were observed in the species $C$. vazzoleri than in other peacock bass species. This may reflect reduced mobilization of this biochemical compound in the blood, which may be caused by anemia. This situation remained unproven in the present study. Issues relating to reproduction and other biotic factors need to be further investigated. The total protein levels found were lower than those found in tambaqui (Colossoma macropomum) $\left(2.8 \pm 0.2\right.$ g.dL $\left.\mathrm{dL}^{-1}\right)$ by Inoue et al. (2016). This difference can be correlated with the style of activity of each species.

The glucose levels were higher in C. temensis. This indicates that the source of energy arose through breakdown of the most efficient glycogen for that species. It may also have been due to intraspecific variation, which was demonstrated through the large difference that was observed between the minimum and maximum values. In C. macropomum, the plasma glucose levels were higher $\left(45.4 \pm 7.2 \mathrm{mg} \cdot \mathrm{dL}^{-1}\right)$ (Inoue et al., 2016) than those of the peacock bass of Balbina lake. This can be attributed to the greater natatory activity of peacock bass species.

Regarding total cholesterol levels, there was similarity among the three species. On the other hand, Ramos et al. (2014) reported that the total cholesterol levels were higher $\left(6.74 \pm 1.85\right.$ mM.L $\left.{ }^{-1}\right)$ in pirarucus (Arapaima gigas) originating from black water, with carnivorous feeding habits. These differences can be correlated with life habits or with differences in body profile. Urea levels were only lower in C. vazzoleri. This characteristic was also observed regarding total protein levels, which was expected because urea is a product from the protein excretion process. In the present study, the urea values were higher than what was seen in pirarucus $\left(0.12 \pm 0.01\right.$ g.L $\left.\mathrm{L}^{-1}\right)$ by Ramos et al. (2014).

In general, ion compositions are extremely important in relation to homeostasis among fish, both in the natural environmental and in situations of captivity (Aride et al., 2007). There were variations in chloride levels in C. temensis, which were lower than those in other species. This can be related to the seasonal differences that exist in Balbina lake or to differentiation of microhabitats.

The sodium and potassium levels were similar in the three species. The sodium levels found in the present study were larger than those found for pirarucus $\left(105.3 \pm 6.7 \mathrm{mM} . \mathrm{L}^{-1}\right)$. The potassium levels in the 
peacock bass species were similar to those of pirarucus $\left(11.8 \pm 0.9\right.$ mM.L $\left.{ }^{-1}\right)$ (Ramos et al., 2014).

Analysis on the water types from which the species were collected showed that $C$. temensis inhabits waters that are more acidic than those occupied by the other species. However, the temperature of the water and the dissolved oxygen levels were similar among C. monoculus, C. temensis and C. vazzoleri.

\section{Acknowledgements}

The authors are grateful to the Support Program for Scientific Development and Technological Innovation (PADCIT) of the Federal Institute of Education, Science and Technology of Amazonas (IFAM) (proclamation nos. 008/2014 and 001/2016), for the projects "Physiological parameters and Cichla spp. of Balbina lake: support for management and conservation and applicability for fish farming" and "Monitoring of the welfare of fish of economic importance for the state of Amazonas", respectively; to the Postgraduate Program on Fisheries Science in the Tropics (PPG-CIPET); and to the Coordination Office for Improvement of Higher-Education Personnel (CAPES), for the scholarship granted to the first author. Thanks, are also due to the anonymous reviewers for their truly helpful comments.

\section{References}

ALMEIDA-VAL, V.M.F., VAL, A.L. and WALKER, I., 1999. Long-and short-term adaptation of Amazon fishes to varying O2-levels: intra-specific phenotypic plasticity and interspecific variation. In: V.M.F. ALMEIDA-VAL and A.L. VAL, eds. Biology of tropical fishes. Manaus: INPA, pp. 185-206.

ARIDE, P.H.R., FERREIRA, M.S., DUARTE, R.M., OLIVEIRA, A.M., FREITAS, D.V., SANTOS, A.L.W., NOZAWA, S.R. and VAL, A.L., 2010. Ascorbic acid (vitamin C) andiron concentration in tambaqui, Colossoma macropomum, iron absorption. Journal of the World Aquaculture Society, vol. 41, no. 2, pp. 291-297. http://dx.doi.org/10.1111/j.1749-7345.2010.00370.x.

ARIDE, P.H.R., OLIVEIRA, A.M., BATISTA, R.B., FERREIRA, M.S., PANTOJA-LIMA, J., LADISLAU, D.S., CASTRO, P.D.S. and OLIVEIRA, A.T., 2018. Changes on physiological parameters of tambaqui (Colossoma macropomum) fed with diets supplemented with Amazonian fruit Camu camu (Myrciaria dubia). Brazilian Journal of Biology $=$ Revista Brasileira de Biologia, vol. 78, no. 2, pp. 360-367. http://dx.doi.org/10.1590/1519-6984.169442. PMid:28954015

ARIDE, P.H.R., ROUBACH, R. and VAL, A.L., 2007. Tolerance response of tambaqui Colossoma macropomum (CUVIER) to water pH. Aquaculture Research, vol. 38, no. 6, pp. 588-594. http://dx.doi.org/10.1111/j.1365-2109.2007.01693.x.

FERREIRA, M.S., ARIDE, P.H.R., SILVA, M.N.P. and VAL, A.L., 2013. Efeito da quantidade de proteína na dieta e treinamento físico sobre parâmetros fisiológicos e zootécnicos de matrinchã (Brycon amazonicus, Günther 1869). Acta Amazonica, vol. 43, no. 4, pp. 439-446. http://dx.doi.org/10.1590/S0044-59672013000400005.

INOUE, L.A.K.A., OLIVEIRA, P.M., GUSMÃO, E.A., LIMA, B.C. and TAVARES-DIAS, M., 2016. Growth, parasitic infection and hematology in Cuvier, 1818 fed diets containing. Journal of Applied Ichthyology, vol. 32, pp. 1-5. http://dx.doi.org/10.1111/ jai.13086.

IWAMA, G. and NAKANISHI, T., 1996. The fish immune system: organism, pathogen and environment. San Diego: Academic Press, $380 \mathrm{p}$.

KORI-SIAKPERE, O., AKE, J.E.G. and IDOGE, E., 2005. Haematological characteristics of the African snakehead, Parachanna obscura. African Journal of Biotechnology, vol. 4, pp. 527-530.

KULLANDER, S.O. and FERREIRA, E.J.G., 2006. A review of the South American cichlid genus Cichla, with descriptions of nine new species (Teleostei: cichlidae). Ichthyological Exploration of Freshwaters, vol. 17, no. 4, pp. 289-398.

KULLANDER, S.O., 1998. A phylogeny and classification of the South American Cichlidae (Teleostei: Perciformes). In: L.R. MALABARBA, R.E. REIS, R.P. VARI, Z.M.S. LUCENA and C.A.S. LUCENA, eds. Phylogeny and classification of Neotropical fishes. Porto Alegre: EdiPUCRS, pp. 461-498.

OLIVEIRA, A.T., ARAÚJO, M.L.G., LEMOS, J.R.G., SANTOS, M.Q.C., PANTOJA-LIMA, J., ARIDE, P.H.R., TAVARES-DIAS, M. and MARCON, J.L., 2017a. Ecophysiological interactions and water-related physicochemical parameters among freshwater stingrays. Brazilian Journal of Biology $=$ Revista Brasileira de Biologia, vol. 77, no. 3, pp. 616-621. http://dx.doi.org/10.1590/15196984.01816. PMid:27783760.

OLIVEIRA, A.T., ARAÚJO, M.L.G., PANTOJA-LIMA, J., ARIDE, P.H.R., TAVARES-DIAS, M., BRINN, R.P. and MARCON, J.L., 2017b. Cyrilia sp. (Apicomplexa: Haemogregarinidae) in the Amazonian freshwater stingray Potamotrygon wallacei (cururu stingray) in different hydrological phases of the Rio Negro. Brazilian Journal of Biology $=$ Revista Brasileira de Biologia, vol. 77, no. 2, pp. 413-416. http://dx.doi.org/10.1590/15196984.00416. PMid:27533723.

OLIVEIRA, A.T., SANTOS, M.Q.C., ARAÚJO, M.L.G., LEMOS, J.R.G., SALES, R.S.A., PANTOJA-LIMA, J., TAVARES-DIAS, M. and MARCON, J.L., 2016. Hematological parameters of three freshwater stingray species (Chondrichthyes: Potamotrygonidae) in the middle Rio Negro, Amazonas state. Biochemical Systematics and Ecology, vol. 69, pp. 33-40. http://dx.doi.org/10.1016/j. bse.2016.07.002.

OLIVEIRA, A.T., CRUZ, W.R., PANTOJA-LIMA, J., ARAÚJO, S.B., ARAÚJO, M.L.G., MARCON, J.L. and TAVARES-DIAS, M., 2011. Morphological and cytochemical characterization of thrombocytes and leukocytes in hatchings of three species of Amazonian freshwater turtles. Veterinarski Arhiv, vol. 81, no. 5, pp. 657-670

OLIVEIRA, A.T., SANTOS, M.Q.C., PANTOJA-LIMA, J., MACHADO, M.R.F., LEMOS, J.R.G., TAVARES-DIAS, M. and ARIDE, P.H.R., 2017c. First record of microfilaria in the blood of black caiman Melanosuchus niger (Crocodylia: Alligatoridae) specimens from the Amazon River basin. Brazilian Journal of Biology = Revista Brasileira de Biologia, vol. 77, no. 4, pp. 895897. http://dx.doi.org/10.1590/1519-6984.04716. PMid:28300941.

PARMA-CROUX, M.J., 1994. Some haematological parameters in Prochilodus lineatus (Pisces, Curimatidae). Revue d'Hydrobiologie Tropicale, vol. 27, pp. 113-119.

PAVLIDIS, M., FUTTER, W.C., KATHARIOS, P. and DIVANACH, P., 2007. Blood cells of six Mediterranean mariculture fish species. Journal of Applied Ichthyology, vol. 23, no. 1, pp. 70-73. http:// dx.doi.org/10.1111/j.1439-0426.2006.00771.x. 
RAMOS, C.A., RAULINO, J.C.N., MENEZES, G.C., CARMO, I.B., BRASIL, E.M., AFFONSO, E.G., COSTA, O.T.F. and FERNANDES, M.N., 2014. Influence Amazonian white and black waters influences on the hematological and biochemical plasma features of Arapaima gigas (Osteoglossiforme). Journal of Life Science, vol. 8, pp. 252-261.

RANZANI-PAIVA, M.J.T. and GODINHO, H.M., 1983. Sobre células sangüíneas e contagem diferencial de leucócitos e eritroblastos em curimbatá, Prochilodus scrofa Steindacher, 1881 (Osteichthyes, Cypriniformes, Prochilodontidae). Revista Brasileira de Biologia, vol. 43, no. 4, pp. 331-338.

RANZANI-PAIVA, M.J.J., SOUZA, A.T.S., PAVANELLI, G.C., TAKEMOTO, R.M. and EIRAS, A.C., 2000. Hematological evaluation in commercial fish species in the floodplain of the upper Paraná River, Brazil. Acta Scientiarum, vol. 22, no. 2, pp. 507-513.

SANTOS, G.M., FERREIRA, E.J.G. and ZUANON, J.A.S., 2006. Peixes comerciais de Manaus. Manaus: Ibama/ProVárzea, 144 p.

SIEGEL, S. and CASTELLAN, N. 2006. Estatística Não-Paramétrica para ciências do comportamento. Porto Alegre: Artmed, $448 \mathrm{p}$.

TAVARES-DIAS, M. and MORAES, F.R., 2003. Características hematológicas da Tilapia rendalli Boulenger, 1896 (Osteichthyes: Cichlidae) capturada em "pesque-pague" de Franca, São Paulo, Brasil. Bioscience Journal, vol. 19, pp. 103-110.

TAVARES-DIAS, M. and MORAES, F.R., 2004. Hematologia de peixes teleósteos. Ribeirão Preto: Villimpress, 144 p.

TAVARES-DIAS, M. and MORAES, F.R., 2007. Leukocyte and thrombocyte reference values for channel catfish (Ictalurus punctatus Raf.), with an assessment of morphological, cytochemical, and ultrastructural features. Veterinary Clinical Pathology, vol. 36, no. 1, pp. 49-54. http://dx.doi.org/10.1111/j.1939-165X.2007. tb00181.x. PMid:17311194.
TAVARES-DIAS, M. and SADRIM, E.F.S., 1988. Influence of anticoagulants and blood storage on hematological values in tambaqui, Colossoma macropomum. Acta Scientiarum, vol. 20, pp. 151-155. http://dx.doi.org/10.4025/actascibiolsci. v20i0.4465.

TAVARES-DIAS, M., BOZZO, F.R., SANDRIN, E.F.S., CAMPOS FILHO, E. and MORAES, F.R., 2004. Células sangúíneas, eletrólitos séricos, relação hepato e esplenosomática de carpacomum, Cyprinus carpio (Cyprinidae) na primeira maturação gonadal. Acta Scientiarum, vol. 26, no. 1, pp. 73-80.

TAVARES-DIAS, M., MONTEIRO, A.M.C., AFFONSO, E.G. and AMARAL, K.D.S., 2011. Weight-length relationship, condition factor and blood parameters of farmed Cichla temensis Humboldt, 1821 (Cichlidae) in central Amazon. Neotropical Ichthyology, vol. 9, no. 1, pp. 113-119. http://dx.doi.org/10.1590/S167962252011005000010 .

VAL, A.L., AFFONSO, E.G. and ALMEIDA-VAL, V.M.F., 1992. Adaptive features of Amazon fishes: blood characterísticas of curimatã (Prochilodus cf. nigricans), Osteichthyes). Physiological Zoology, vol. 65, no. 4, pp. 832-843. http://dx.doi.org/10.1086/ physzool.65.4.30158542.

WILHELM FILHO, D., EBLE, G.J., KASSNER, G., CAPRARIO, F.X., DAFRÉ, A.L. and OHIRA, M., 1992. Comparative hematology in marine fish. Comparative Biochemistry and Physiology A: Comparative Physiology, vol. 102, no. 2, pp. 311-321. http:// dx.doi.org/10.1016/0300-9629(92)90141-C. PMid:1354580.

WINTROBE, M.M., 1934. Variations on the size and hemoglobin content of erythrocytes in the blood of various vertebrates. Folia Haematologica: Internationales Magazin fur Blutforschung, vol. 51, pp. 32-49.

ZAR, J., 1999. Biostatistical analyses. New Jersey: Printice Hall. 